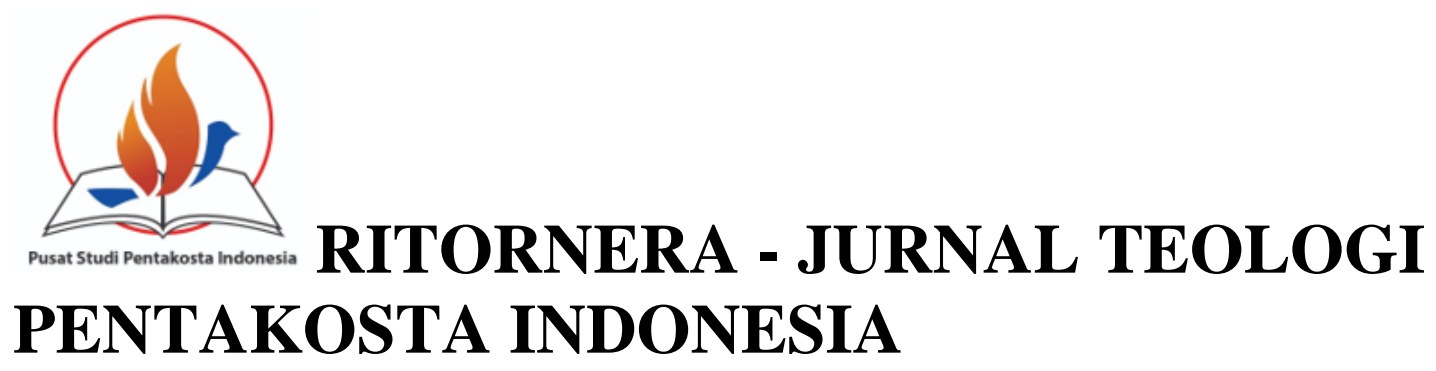

Vol. 1, No. 2, August 2021

Available at: pspindonesia.org

\title{
Christ is Our Message
}

John H. King

jhking@comcast.net

\begin{abstract}
As Pastor David Platt, Lead Pastor at McLean Bible Church in Washington, D.C., so aptly states it, "The Gospel is the lifeblood of Christianity." Herein lies the Christian motive;" states the 1928 Missionary Council, "it is simple. We cannot live without Christ and we cannot bear to think of men living without Him." To Dr. Platt the challenge is "how to live out that gospel in our lives, families, and churches in an age of sexual confusion, legal abortion, rampant materialism, violent racism, escalating refugee crises, diminishing religious liberties, and a number of other significant social issues." In his work "From Christendom to Apostolic Mission" Bishop Kagan, the Bishop of Bismarck, North Dakota, sees the necessity for the Church to once again don the mantle of the missionary since we are no longer living in a christian culture. Stanley Hauerwas, an American theologian, ethicist, in his work, "The Christian Difference, or Surviving Postmodernism," called ours "a life and death struggle with the world." ... adding: "I think it is a serious mistake not to take postmodernism seriously." Hauerwas saw believers as "a community-in-exile." (Postmodernism is a world-weary intellectualism that no longer views life in terms of absolutes or universal principles. They go so far as to say that all thought is equally relevant (that there are no boundaries, no rules, no hierarchies, no objective reality and all facts are just 'social constructs.') As Dr. Platt writes, “As followers of Christ, we are fooling ourselves if we don't face the reality that belief in and obedience to the Bible in an anti-Christian age will inevitably lead to risk in one's family, future, relationships, reputation, career, and comfort in this world." The world puts their faith in an evolutionary progress not in God. According to Genesis 1 God is first our Creator. Creationism has nothing in common with evolutionary theory. Evolutionary theory suggests we are heading toward a utopian world where "survival of the fittest" is a natural process leaving the best of the best instead of a divine providence that plans an end to sin and corruption. Postmodern thought and evolutionary theory counters what Christian eschatology is all about. God as our Creator made us, for His glory. If this were untrue, Romans 3:23 would be nonsense, since we cannot fall short of a relationship that a materialistic postmodernism says doesn't exist. Sin and God's judgment is now mocked by the doctrine that knowledge, truth, and morality only exist in relation to culture. Christendom has been replaced with a materialistic reality. We are, in simple truth, missionaries to cultural change. Christian apologist J. F. Baldwin recognizes the importance of heroic, Spirit-filled living, as the most powerful argument beckoning nonbelievers to the faith.
\end{abstract}


"Modern man listens more willingly to witnesses than to teachers," Pope Paul the Sixth observed. We now, as Peter, must settle the matter in our hearts. The effort to silence us must fail. When it comes to the Gospel message of the Cross, "We must obey God rather than people" (Acts 5:29)

Keywords: Christ is Our Message, Gospel, Christian, Postmodernism

\section{Abstrak}

Seperti yang dikatakan oleh Pendeta David Platt, Pendeta Utama di Gereja Alkitab McLean di Washington, D.C., dengan tepat menyatakannya, "Injil adalah sumber kehidupan Kekristenan." Di sinilah letak motif Kristen;" menyatakan Dewan Misionaris 1928, "sederhana. Kita tidak bisa hidup tanpa Kristus dan kita tidak tahan memikirkan manusia yang hidup tanpa Dia.” Bagi Dr. Platt tantangannya adalah "bagaimana menghidupi Injil itu dalam kehidupan kita, keluarga, dan gereja di zaman kebingungan seksual, aborsi legal, materialisme yang merajalela, rasisme yang kejam, meningkatnya krisis pengungsi, berkurangnya kebebasan beragama, dan sejumlah masalah sosial penting lainnya." Dalam karyanya "From Christendom to Apostolic Mission" Uskup Kagan, Uskup Bismarck, North Dakota, melihat perlunya Gereja sekali lagi mengenakan jubah misionaris karena kita tidak lagi hidup dalam budaya kristen. Stanley Hauerwas, seorang teolog, ahli etika Amerika, dalam karyanya, "The Christian Difference, or Surviving Postmodernism," menyebut karya kita "perjuangan hidup dan mati dengan dunia." ...menambahkan: "Saya pikir adalah kesalahan serius untuk tidak menganggap serius postmodernisme." Hauerwas melihat orang-orang percaya sebagai "komunitas di pengasingan." (Postmodernisme adalah intelektualisme yang melelahkan dunia yang tidak lagi memandang kehidupan dalam kerangka prinsip-prinsip absolut atau universal. Mereka melangkah lebih jauh dengan mengatakan bahwa semua pemikiran sama-sama relevan (bahwa tidak ada batasan, tidak ada aturan, tidak ada hierarki, tidak ada realitas objektif). dan semua fakta hanyalah 'konstruksi sosial.') Seperti yang ditulis Dr. Platt, "Sebagai pengikut Kristus, kita membodohi diri sendiri jika kita tidak menghadapi kenyataan bahwa kepercayaan dan ketaatan kepada Alkitab di zaman antiKristen pasti akan membawa risiko dalam keluarga, masa depan, hubungan seseorang. , reputasi, karier, dan kenyamanan di dunia ini." Dunia menaruh kepercayaan mereka pada kemajuan evolusioner bukan pada Tuhan. Menurut Kejadian 1 Tuhan adalah Pencipta kita yang pertama. Kreasionisme tidak memiliki kesamaan dengan teori evolusi. Teori evolusi menunjukkan bahwa kita sedang menuju dunia utopis di mana "survival of the fittest" adalah proses alami meninggalkan yang terbaik dari yang terbaik alih-alih pemeliharaan ilahi yang merencanakan untuk mengakhiri dosa dan korupsi. Pemikiran postmodern dan teori evolusi menentang apa yang dimaksud dengan eskatologi Kristen. Allah sebagai Pencipta kita menciptakan kita, untuk kemuliaan-Nya. Jika ini tidak benar, Roma 3:23 akan menjadi omong kosong, karena kita tidak dapat mengabaikan hubungan yang menurut postmodernisme materialistis tidak ada. Dosa dan penghakiman Tuhan sekarang diejek oleh doktrin bahwa pengetahuan, kebenaran, dan moralitas hanya ada dalam kaitannya dengan budaya. Susunan Kristen telah digantikan dengan realitas materialistis. Kami, dalam kebenaran sederhana, misionaris untuk perubahan budaya. Pembela Kristen J. F. Baldwin mengakui pentingnya kehidupan yang heroik dan dipenuhi Roh, sebagai argumen paling kuat yang memberi isyarat kepada orang-orang yang tidak percaya kepada iman. "Manusia modern lebih bersedia mendengarkan saksi daripada guru," Paus Paulus Keenam mengamati. Kita sekarang, sebagai Peter, harus menyelesaikan masalah ini di dalam hati kita. Upaya untuk membungkam kita harus gagal. Ketika sampai pada pesan Injil tentang Salib, "Kita harus lebih taat kepada Allah daripada kepada manusia" (Kisah Para Rasul 5:29) 


\section{INTRODUCTION}

Jesus's mission which sent Him to the Cross is not only central to all Christian truth, it is all Christian Truth. "I decided to know nothing among you," Paul vowed to the Corinthian Church, “except Jesus Christ and him crucified." (1 Corinthians 2:2) The Holy Spirit's entire ministry revolves around Jesus: His life, death, resurrection and intercessory ministry. "When the Spirit of truth comes he will guide you into all truth." Jesus comforted eleven disillusioned followers, who were unsettled by His talk of crucifixion. Then the Savior explained, "For he will not speak on his own (King James Version: of Himself), ... He will glorify me.” (John 16:13-14a) The metaphor that might emphasize this truth: enrolling in a college course because you hear that the Holy Spirit is on staff as one of the instructors, but the only course He teaches is Jesus 101 . We want to learn so much more: eschatology, comparative religions, church history, demonology, to name a few, but the Spirit seems disinterested in these. His curriculum is Jesus's incarnation, Jesus's death, Jesus's resurrection, and Jesus's intercession now at the right hand of the Father. (And if we inquirer when Jesus or the Father will be offering these courses, they're not. Acts 1:8)

This would have been most uplifting if we might imagine now spending endless days in school and in praise of our Lord's victory over sin and the devil. But we have a world with whom to share this good news (John 17:15-16). Admit it: We are missionaries, ambassadors of reconciliation (2 Corinthians 5:18-19). We have a message from God for a world where many do not want to hear it. We are sifting through the debris of a-spiritually speaking-crumbling cultural awareness of the love of God, looking for-if I may use the parable - those priceless (precious) pearls for whom our Lord gave everything to make His own (Matthew 13:46). 


\section{LITERATURE \& DISCUSSION}

\section{The Lifeblood of Christianity}

As Pastor David Platt, Lead Pastor at McLean Bible Church in Washington, D.C., so aptly states it, "The Gospel is the lifeblood of Christianity." ${ }^{1}$ The missionary council meeting in Jerusalem in 1928 expanded, "The Gospel is the answer to the world's greatest need. It is not our discovery or achievement; it rests on what we recognize as an act of God." "2 As believers, the Savior in our life is beyond question our trumpet call, our motive for living. Herein lies the Christian motive;" states the 1928 Missionary Council, "it is simple. We cannot live without Christ and we cannot bear to think of men living without Him. Christ is our motive."3

To Dr. Platt the challenge is "how to live out that gospel in our lives, families, and churches in an age of sexual confusion, legal abortion, rampant materialism, violent racism, escalating refugee crises, diminishing religious liberties, and a number of other significant social issues." ${ }^{4}$ In his work "From Christendom to Apostolic Mission” Bishop Kagan, the Bishop of Bismarck, North Dakota, sees the necessity for the Church to once again don the mantle of the missionary since we are no longer living in a christian culture. Archbishop Fulton Sheen in 1974 said "We are at the end of Christendom. Not of Christianity, not of the Church, but of Christendom. Christendom is

\footnotetext{
${ }^{1}$ David Platt, Counter Culture: Following Christ in an Anti-Christian Age. (Carol Stream, Ill: Tyndale House Publishers, Inc.,2017), p. 1

${ }^{2}$ Francis M. DuBose. ed. Classics of Christian Missions. (Nashville, TN: Broadman Press, 1979 ), p. $343 \mathrm{ff}$

${ }^{3}$ Ibid. $343 \mathrm{ff}$

${ }^{4}$ David Platt, Counter Culture: Following Christ in an Anti-Christian Age. (Carol Stream, Ill: Tyndale House Publishers, Inc.,2017 ), Introduction
} 
... social life as inspired by Christian principle. That is ending-we've seen it die." ${ }^{55}$ Graham Ward's “Anthology of Christian Essays on Christianity's Survival” included an article by Stanley Hauerwas: ${ }^{6}$ "The Christian Difference, or Surviving Postmodernism." The fact that Ward could compile such a work is itself a testament to the church's awareness of what Hauerwas called "a life and death struggle with the world."7 ...adding: "I think it is a serious mistake not to take postmodernism ${ }^{8}$ seriously." ${ }^{9}$ Hauerwas saw believers as "a community-in-exile." ${ }^{10}$ Sounds Pauline: "Our citizenship is in heaven, and we eagerly wait for a Savior from there, the Lord Jesus Christ." (Philippians 3:20)

We are, in simple truth, missionaries to cultural change. And we must let that missionary side of our love realize more its potential in the hand of God. Jesus-yes - offends a world that does not know who He is, but His life is what our lives are all about. "in him we live, and move, and have our being...." (Acts 17:28) Christian apologist J. F. Baldwin recognizes the importance of heroic, Spirit-filled living, as the most powerful argument beckoning nonbelievers to the faith: "We may certainly teach people about God's grace by telling them the story of Pilgrim's Progress; ... we teach it best when we demonstrate it with our lives. Our actions matter more than any

${ }^{5}$ Bishop David D. Kagan. From Christendom to Apostolic Mission: Pastoral Strategies for an Apostolic Age. (Bismarck, ND: University of Marry Press, 2020), Preface

${ }^{6}$ Stanley Martin Hauerwas is an American theologian, ethicist, and public intellectual. Hauerwas was a longtime professor at Duke University, serving as the Gilbert T. Rowe Professor of Theological Ethics at Duke Divinity School with a joint appointment at the Duke University School of Law. - Wiki

${ }^{7}$ Graham Ward ed. Postmodern Theology. University of Manchester: (Blackwell Publishing Ltd. 2008), p. 145

${ }^{8}$ Postmodernism is a world-weary Intellectualism that no longer views life in terms of absolutes or universal principles. They go so far as to say that all thought is equally relevant (that there are no boundaries, no rules, no hierarchies, no objective reality and all facts are just 'social constructs');

${ }^{9}$ ibid.

${ }^{10}$ ibid. p. 153. 
words." "Modern man listens more willingly to witnesses than to teachers," Pope Paul the Sixth observed, "and if he does listen to teachers, it is because they are witnesses." ${ }^{12}$ And Bishop Kagan gave us the definition of witness: "They need to know, from their own experience, that obedience to the Gospel is perfect freedom, that holiness leads to happiness, that a world without God is a desolate wasteland, and that new life in Christ transforms darkness into light." ${ }^{\prime 3}$ The ultimate test of a disciple's commitment and dedication to the Lord is their ability to represent the Good Newsas only good news can be represented-with an undying hope, an enduring peace, an unconquerable love, an unquestioning faith, and an unquenchable joy.

\section{The Rough-edge of Christianity}

Perhaps, in the spirit of filing off the rough-edge of the offense, Sharon Baker suggested that "we reinterpret our tradition (in a way). that it remains relevant for our changing world and powerful enough to transform our world with the good news of salvation through Jesus Christ."14 Dr. Craig maintains that there is a reasonable argument to be made for the Savior's crucifixion that will draw the non-believer into conversation about their sinfulness and their need for a Savior. "What is needed," he offers, "is a defense of the coherence and morality of one's theory of the atonement using the best tools of philosophical analysis and argumentation. Only then will one's theory of the atonement commend itself to thinking men and women today." $" 15$ Perhaps.

${ }^{11}$ Kenneth W. Daniels, Why I Believed: Reflections of a Former Missionary. (Austin TX: , 2010. Kindle Edition), p. 101

12 Pope St Paul VI, Evangelii Nuntiandi, 41 cp. Bishop Kagan. p. 35

${ }^{13}$ Bishop Kagan. p. 37

${ }^{14}$ Sharon Baker. Executing God (Louisville, KY: Westminster John Knox Press, 2013), p. 6

15 William Lane Craig. Atonement and the Death of Christ: An Exegetical, Historical, and Philosophical Exploration. (Waco, TX. Baylor University Press. 2020), p. 9 
But Jesus, Himself, cautioned that, there is nothing we can do or say that will make more palatable a truth that confronts society on the most basic of levels - its morality or lack thereof. If there is talk of a "hell" (and Jesus did speak of it) it aggravates the offense. No wonder our Lord unabashedly admitted, "You will be hated by all nations because of my name." (Matthew 24:9) And if the Spirit gets us into trouble, He will get us out (Luke 12:11).

And where can we run and hide in God's Word? Where are the words that only console the sinner with a universal hope of grace that suggests there are many roads to God, that somehow what we called "sin" isn't that at all but just a faltering part of our humanity, a genetic defect, an illness? Is there nothing in the Good Book that condones or supports cultural change, that sees social evolution as simply different from what it once was? Must grandma's traditions and beliefs still be relevant? Can we not find a biblical position that allows us the liberty to be different, to be living a new morality? Surely in a book the size of the Bible there has to be some thread of truth that supports the postmodern approach to social change?

No!

The Bible is one continuous message. It reflects on the broken relationship we have with the God Who created us and still loves us though we rejected and ignored that love. It is the message of reconciliation, forgiveness, and redemption through the ultimate act of selfless, divine, love on a Roman Cross.

Everyone of us stands before Him guilty of walking away, of seeing no value in loving God back—-something God called sin. “...all have sinned” (Romans 3:23) A relationship always takes two but how to transform the heart of a humanity that had no passion for Him, was the gargantuan task. We simply didn't want God! 
Whether we want to admit it or not, the entire Bible is God's way of telling us this simple but profound truth. The Bible is all about Him, our need of redemption and how God would provide it. As Jesus explained to two disciples one day along a country road as they walked: “...beginning with Moses and all the Prophets, he (Jesus). interpreted for them the things concerning himself in all the Scriptures."16 'All' is the operative word. The Biblical record offers nothing else to us than our salvation thru Christ. There is no other path back into fellowship with God. "Jesus (said), "I am the way... No one comes to the Father except through me." (John 14:6) Jesus is the only way and that, too, is an abrasive and impertinent attitude toward other religions that think to hold a claim on spiritual or moral truth.

\section{It's All About The Blood}

"We were reconciled to God through the death of his Son." (Romans 5:10) Christianity is, indeed, a bloody religion, an idea, perhaps, in itself offensive to logical minds, to academicians who reason from a scientific perspective, and who see no value in the death of a "would-be" Savior.

But with an unapologetic conviction, this is what our faith is all about! This is our living hope: the glorious return of the great God even our Savior, Jesus Christ (Titus 2:13) who shed His blood on a cross on our behalf, in our stead, to reconcile us to God. "We have redemption through his blood, the forgiveness of our trespasses.." (Ephesians 1:7) This has become our trumpet sound as believers. Paul unambiguously declared “... through him to reconcile everything to himself ... by making peace through his blood, shed on the cross." (Colossians 1:20)

${ }^{16}$ Luke 24:27 
The Savior's shed blood is the only explanation that ought to satisfy faith, that ought to satisfy any inquiry into any theory of the atonement. The writer to the Hebrews agreeably wrote, "How much more will the blood of Christ, who through the eternal Spirit offered himself without blemish to God, cleanse our consciences from dead works so that we can serve the living God?" (Hebrews 9:14) This is redemption, freedom from sin's hold on us. In Peter's words, 'For you know that you were redeemed from your empty way of life ..., not with perishable things like silver or gold, but with the precious blood of Christ,..." (1 Peter 1:18-19)

More to the point of atonement our Lord's incarnation was necessary that by His death He would defeat Satan at his own game, wrest death from Satan's hand providing eternal life for all those who would by faith accept (faith is accepting). our Savior's victory, so valiantly fought and won! "Now since the children have flesh and blood in common, Jesus also shared in these, so that through his death he might destroy the one holding the power of death — that is, the devil." (Hebrews 2:14)

The Old Testament is replete with references to sacrifices because sacrifice means shed blood. All along, the Father had His Son's death on His mind and heart. There can be no other explanation worthy our theology. "For the life of a creature is in the blood, and I have appointed it to you to make atonement on the altar for your lives, since it is the lifeblood that makes atonement." (Leviticus 17:11) "Without the shedding of blood," the writer to the Hebrews affirms, “there is no forgiveness." (Hebrews 9:22) "We have redemption through his blood." (Colossians 1:14) This is atonement, plain and simple. What is eternal life to a believer, is philosophical garble to the unbeliever until through conviction the Spirit of God reveals it. It is every believer's privilege to herald the message for the sake of those who will really listening. 


\section{The Confrontation}

But this message runs counter to the cultural changes in the civilized world as Dr. Platt writes, “As followers of Christ, we are fooling ourselves if we don't face the reality that belief in and obedience to the Bible in an anti-Christian age will inevitably lead to risk in one's family, future, relationships, reputation, career, and comfort in this world."17

Our worldview as well as our faith defends the deity of Jesus as well as the trinity, the virgin birth, and ultimately the death of our Savior, all as central to our message, but all of which, sounds like mythological nonsense to the non-believing heart. "We preach Christ crucified, a stumbling block to the Jews and foolishness to the Gentiles." (1 Corinthians 1:23)

Make no mistake about it: The Bible is the promise of Salvation offered thru Christ's death — a message that counters today's evolutionary worldview of an eventual utopia, a self-made heaven for mankind. The Cross represents a miracle of grace that science cannot confirm or deny because it is outside the realm of natural inquiry. The resurrection from the dead and what it means for believers has broken out of the confines of natural history. "(Christianity's). critical edge,"

Graham Ward cautions, "is important for the way it [is] ... outside the secular value-system." 18 In English: as Jesus prayed to the Father, "I have given them your word. The world hated them because they are not of the world, just as I am not of the world.” (John 17:14)

\footnotetext{
${ }^{17}$ David Platt. Introduction

${ }^{18}$ Graham Ward. xxiii
} 
The Cross is a message that runs counter to the social change evident within a, so-called, civilized world. God's Word, therefore, has continuity and unity of thought. There is only one message within its pages! Discussions around topics, like a nuclear family or infanticide, that appear peripheral and less important have been dragged into dialogue because we cannot escape certain conclusions about the God we are getting to know and to love. Somehow, we have discovered, that our faith, our love for God, our salvation, is a wisdom crying in the streets (Proverbs 1:20) pleading with us not to be lured in by fancy phrases or ensnared by notions of compromise with otherwise worldly concepts that ultimately lead to denying who we are or who we want to become in Christ.

Now on the eve of Christ's return, this makes our voice as necessary as it is unwelcome. The church needs to consider the danger of compromise like playing a linguistic shell game or sleight of definition with words like "faith is just opinion" "love is just a feeling" designed only as a palliative approach to mitigate the pain of confrontation. Sin is sin and needs to be dealt with if we care anything at all about meeting God someday without fear.

Our faith is not an aspirin, a cognitive dissonance that denies reality. Christian faith is the boldest move we can make. Instead of denying or projecting blame, admitting what we had become and our estrangement from God, we ask God to forgive us - to appropriate the forgiveness of God, if you prefer-and show how to live above our past rebellion against Him.

\section{God's Involvement with Mankind}

Let's go back to Genesis 1:1. God was not first our Savior. He was first our Creator and the new birth is His work. He is the Creator. But there's the rub! Creationism has nothing in common with evolutionary theory. Evolutionary theology suggests God made man not from the 
dust of the ground but from a monkey. Evolutionary theory suggests we are heading toward a utopian world where "survival of the fittest" is a natural process leaving the best of the best instead of a divine providence that plans an end to sin and corruption. Postmodern thought, evolutionary theory, counters what Christian eschatology and the Apocalypse is all about.

Weakening the idea of God as our Creator weakens the reason why He made us, for His glory. And if not for His glory, then Romans 3:23 is nonsense, since we cannot fall short of a relationship that didn’t exist. In other words, no Creator God means no reality to the concept of sin. Sin and God's judgment is now mocked by a postmodern relativism, the doctrine that knowledge, truth, and morality exist in relation to culture, society, or historical context, and are not absolute. And need I warn the Christian where this leads? Jesus's death for sin becomes a moot point. It has been replaced with a materialistic understanding of reality. Materialism has two definitions. Take your pick.

- a tendency to consider material possessions and physical comfort as more important than spiritual values. This is a familiar trap that Jesus addresses in the first beatitude. "Blessed are the poor in spirit. (Matthew 5:3) Believer happiness is not invested in possessions but in a dependence on God for all things.

- the doctrine that nothing exists except matter and its movements and modifications. Science is god?

\section{A Powerful Message}

The fifth chapter in The Acts of the Apostles is an historical reference to possibilities when the church learns to unite behind the Gospel. In verse 12 Luke tells us, "Many signs and wonders 
were being done among the people through the hands of the apostles." We read this as if this were a one-off event instead of the possibilities for which the Church was commissioned. Verse 14, no surprise, testifies, "Believers were added to the Lord in increasing numbers..." Governments of the world, take notice!

When the sick were carried on cots out into the streets hoping that Peter might pass by, believing that just the apostle's shadow was enough to heal them, the earthly authorities knew that God was getting out of hand. The theology in Jesus's day was: touch Him to be healed (Mark 6:56). But for the apostles, their shadow was sufficient. (It had to be, obviously, during sunset when a person's shadow was longer and more likely to sweep the crowd along the side of the road or Peter had to step over them!). What a parade! Touch or no touch, it is not a question of theology but of faith, and the crowds were there, swept up in the assurance that God was there and God would heal. They came - I dare say — by the hundreds, and now whoever saw themselves in office were under immense social pressure to stop it.

Verse 17, Luke noted, they were "filled with jealousy." You see (not to preach but, just saying) God gets in the way of the would-be powerful, famous and rich, and they don't like it! "So," verse 18, "they arrested the apostles and put them in the public jail." That is that!

No that wasn't that. The following morning, the political leaders, had to check it out for themselves. Peter and the apostles with him were in the public area, the Temple court, (verse 21) teaching. Teaching what? Verse 28: teaching "in this name" (Jesus's name, i.e. The message of the Cross). 
And how did they get out? I can imagine the soldiers being asked and replying, "Don’t ask, sir!" So now what do we do. An official statement with the force of law should be issued. It should work to silence them.

It didn't. Peter and the others were re-captured and brought before the religious leaders. They're in serious trouble now! Jesus warned them, "You will even be brought before governors and kings because of me." (Matthew 10:18) He gave them a heads-up, "You will be hated by everyone because of my name." (Matthew 10:22) And here we are!

(Reminds one of Martin Luther before the Diet of Wörms, a formal deliberative assembly called by the Emperor Charles V. to deal with this maverick. Luther dared teach against established religious order. According to tradition, Luther is said to have declared "Here I stand, I can do no other," before concluding with "God help me.”)

"Didn't we strictly order you (Peter and those with you). not to teach in this name? (Freedom to speak has limits. Talk about anything or anyone you want, Peter ... but not "Him," not Jesus, not the Cross!). Look, you have filled Jerusalem with your teaching and are determined to make us guilty of this man's blood." This verse is psychologically rich. Peter's message was not one of guilt but it was the Spirit's opportunity to convict (John 16:8). Sad, when someone doesn't see the difference, not knowing that "godly grief produces ... repentance that leads to salvation without regret." (2 Corinthians 7:10) Peter didn't fill Jerusalem with anything ...God did!

But what interests us here is the official executive order that was issued against teaching the Gospel message of the Cross and Peter's and the other's response: They replied, "We must obey God rather than people." (Acts 5:29) 
Make no mistake about it: "the offense of the cross" (Galatians 5:11) is real. We must not be "...ashamed of the gospel, because it (alone). is the power of God for salvation to everyone who believes..." (Romans 1:16) If our message were the misinformed ramblings of a few unrealistic visionaries, we would be more entertaining than threatening (perhaps, an SNL parody in the U.S. we might laugh at). But this is not the case. The Gospel is empowered to change the world, to bring a sweeping spiritual revival that, subsequently, has political consequences for governments that find God somewhere between a nuisance to a genuine providential force that cannot be ignored.

Dorothy Sayers in her inimical way, perhaps, says it best: "It (is) a grave mistake to present Christianity as something charming and popular with no offense in it. Seeing that Christ went about the world giving the most violent offense to all kinds of people, it would seem absurd to expect that the doctrine of His Person can be so presented as to offend nobody. Nobody need be too much surprised or disconcerted at finding that a determined preaching of Christian dogma may sometimes result in a few angry letters of protest or a difference of opinion on the parish council. At the risk of appearing quite insolently obvious, I shall say that if the Church is to make any impression on the modern mind She will have to preach Christ and the Cross."19

"Jesus took our place on Calvary" is the heart of the Gospel message. "So," John Stott reminds us, "substitution is not a "theory of atonement." ${ }^{20}$ Ours is to expound it with conviction, not dress it in logic to make the message less offensive or less unreasonable to the natural mind. The strength of our message is in two things on our part and one on God's. For our part the strength

${ }^{19}$ Dorothy Sayers, Creed Or Chaos. (Manchester,NH: Sophia Institute Press, 1974), p. 8ff

20 John Stott. The Cross of Christ Centennial Edition. (Downers Grove, IL:InterVarsity Press. 2021), p. 199 
of our message depends on the strength of our conviction (faith) that this is real. Second, going back to the introduction to this work: they will know what God does by observing the fruit of His miraculous work in our lives. If fruit trees bear good fruit, no one is trying to understand the root system. If you think of it, a mystery surrounding a total understanding of Calvary leaves somethings for God to reveal later - and I want Him to take all eternity to share this truth. But for now, He is the One who convicts. Our evangelization is not the art of guilting someone into salvation or selling them on it. We introduce them to our Lord and He then takes it from there.

\section{REFERENCE}

Platt, David. Counter Culture: Following Christ in an Anti-Christian Age. (Carol Stream, Ill: Tyndale House Publishers, Inc.,2017)

DuBose, Francis M.. ed. Classics of Christian Missions. (Nashville, TN: Broadman Press, 1979)

Kagan, Bishop David D.. From Christendom to Apostolic Mission: Pastoral Strategies for an Apostolic Age. (Bismarck, ND: University of Marry Press, 2020)

https://en.wikipedia.org/wiki/Stanley_HauerwasWard, Graham. ed. Postmodern Theology. University of Manchester: (Blackwell Publishing Ltd. 2008)

Daniels, Kenneth W. Why I Believed: Reflections of a Former Missionary. (Austin TX: 2010. Kindle Edition)

Baker, Sharon. Executing God (Louisville, KY: Westminster John Knox Press, 2013)

Craig, William Lane. Atonement and the Death of Christ: An Exegetical, Historical, and Philosophical Exploration. (Waco, TX. Baylor University Press. 2020) 
Ritornera - Jurnal Teologi Pentakosta Indonesia, Vol 1, No 2, August 2021

Sayers, Dorothy. Creed Or Chaos. (Manchester,NH: Sophia Institute Press, 1974)

Stott, John. The Cross of Christ Centennial Edition. (Downers Grove, IL:InterVarsity Press. 2021) 